\title{
Anti-Inflammatory and Anti-Remodelling Potential of Ethanol Extract Rhodomyrtus Tomentosa in Combination of Asthma and Coal Dust Models
}

\author{
Fujiati Fujiati ${ }^{1}$, Haryati Haryati*2
}

\begin{abstract}
Background: Combination of asthma and coal dust is a chronic and recurring airway disease related to inflammation cell activation. The Rhodomyrtus tomentosa flowering plants native to South Kalimantan exhibit a broad therapeutic potential, like anti-inflammatory and anti-remodelling properties. This study aims to analyze the effect of ethanol extract of $R$. tomentosa leaves (EERTL) nebulizer on the number of inflammatory cells and histomorphometry of lung tissue in a mice-like model of a combination of asthma and coal dust.
\end{abstract}

Methods: The 24 BALB/c mice were divided into four treatment groups ( $\mathrm{n}=6$ per group), were sensitized with normal saline (K), OVA + coal dust (P1), OVA + coal dust + salbutamol (P2), and OVA + coal dust + EERTL (P3). Eosinophil cells, neutrophils, lymphocytes, epithelial thickness, smooth muscle, fibrosis subepithelial bronchioles, and the number of goblet cells as indicators of anti-inflammatory and antiremodelling airways.

Results: The number of eosinophils, neutrophils, and lymphocytes cells are given salbutamol or EERTL was significantly lower than the OVA-sensitized and coal dust exposure group only. There are meaningful differences in the average thickness of the epithelium, smooth muscle, and subepithelial fibrosis of bronchiolus. The histopathology picture of goblet cells showed an increase in the number and size (hyperplasia) in OVA-sensitized and coal dust exposure compared to another group.

Conclusions: It was concluded that the EERTL nebulizer could reduce inflammatory cells and remodelling process from bronchoalveolar lavage in the mice combination of asthma and coal dust models.

Keywords: Anti-Inflammatory, Anti-Remodelling, Asthma, Coal Dust, Rhodomyrtus tomentosa.

\section{Introduction}

Particulate matter (PM) coal dust is one example of air pollutants widely found in coal mining areas. The Indonesian Geological Agency (2015) reported that South Kalimantan is one of the three largest provinces coal mining producing in Indonesia. Coal mining increases the country's foreign exchange, but on the other hand, coal dust is one of the important air pollutions in coal mining areas. Inhalation of coal dust contributes to increased respiratory diseases, including increased lung remodelling in animals (1-3). One of the mechanisms of lung remodelling related to coal dust components is stimulating the immune response. Based on research, Isthiaq et al. showed that residents living in coal mining areas have a higher risk of exposure to harmful components $(\mathrm{Pb}, \mathrm{Cr}, \mathrm{Cd}, \mathrm{Ni}, \mathrm{Cu}, \mathrm{Co}$,

1: Department Biochemistry and Biomolecular, Faculty of Medicine, Lambung Mangkurat University, Banjarmasin, South Kalimantan, Indonesia.

2: Department Pulmonology and Respiratory Medicine, Faculty of Medicine, Lambung Mangkurat University, Banjarmasin, South Kalimantan, Indonesia.

*Corresponding author: Haryati Haryati; Tel: +62 8125003155; E-mail: haryati@ulm.ac.id.

Received: 22 Nov, 2021; Accepted: 29 Nov, 2021 
and $\mathrm{Zn}$ ) coal dust (4). Coal dust pollution is more dangerous if inhaled in people who have asthma.

Asthma is a chronic inflammatory disorder of the airways due to exposure to allergens or other environmental irritants. Data on asthma in 2018 from various provinces showed that South Kalimantan $(2.8 \%)$ was in the top 9 of 15 provinces with a higher prevalence of asthma, exceeding the national figure $(2.4 \%)$ (5). This phenomenon is thought to be caused by increased exposure from the environment, such as dust, chemicals, pollutants from industry and motor vehicles, and cigarette smoke that can stimulate the expression of pro-inflammatory factors (6). The presence of environmental changes in asthmatics allows for phenotype changes in asthma that are dominant eosinophils. Corticosteroids are a long-term treatment to control asthma. They have major effects reducing inflammatory processes on the walls of the airways, suppressing the expression of various inflammatory cells in the airways, and improving bronchial hyperresponsivity (7). In general, asthma patients respond well to corticosteroid administration, but a small number $(5-10 \%)$ of asthma patients show a poor response and are even unresponsive to corticosteroid administration (8). So, it is necessary to consider treatment with other agents such as herbal plantation for alternative medicine. One of them is the Karamunting plant (Rhodomyrtus tomentosa/R. tomentosa).

Karamunting plant ( $R$. tomentosa) is one of the biodiversity found in the wetlands of South Kalimantan. Based on the research on pharmacological activity, $R$. tomentosa shows various therapeutic potential, including antibacterial, antitumor, anti-inflammatory, and antioxidant activity both in vivo and in vitro (9). Compounds suspected of having pharmacological action in Karamunting plants include triterpenoids, flavonoids, phenols, and meroterpenoids. Research Sutomo et al. explained that part $R$. tomentosa contains alkaloid compounds, flavonoids, phenols, tannins, saponins, and terpenoids (10).

Some plants that contain flavonoids and saponins show anti-inflammatory effects. Flavonoids and saponin essential oils in Cirsium japonicum DC have been shown to have anti-inflammatory effects against lipopolysaccharide (LPS)-induced macrophages (11). Flavonoid compounds, triterpenoid saponins, and licorice residue saponins can lower inflammatory parameters interleukin (IL)-1 $\beta$, IL-6, inducible nitric oxide synthase (iNOS), and cyclooxygenase2 (COX-2) (12). Total extract of saponins from Tribulus terrestris $L$. showed better antiinflammatory activity by lowering nitric oxide (NO) production, tumour necrosis of $\alpha$ (TNF- $\alpha$ ), and decreased phagocytic ability in RAW 264.7 cells stimulated by LPS (13). In addition, flavonoids in Dracocephalum peregrinum $L$. inhibit the signal transforming growth factor-beta-1 (TGF- $\beta 1)$ (14). The TGF- $\beta 1$ molecule is an inflammatory cytokine associated with fibrosis (one of the parameters of lung tissue remodelling) in asthma (15). That plants that contain flavonoids and saponins have the potential to be used as anti-inflammatory and antiremodelling in asthma.

Research by utilizing $R$. tomentosa plants as anti-inflammatory and anti-remodelling with nebulizer methods as new research that can be used as an implementation of one of the strategic issues of Lambung Mangkurat University. It develops Kalimantan Island's potential and rich vegetation, especially in wetlands, to create active compounds based on local wisdom and ethnopharmacology. The study aimed to analyze the effect of extract of $R$. tomentosa leaves (EERTL) administration on the number of eosinophils, neutrophils, and, lymphocytes in bronchoalveolar lavage (BAL) fluid and histomorphometry of lung tissue in a micelike model of a combination of asthma and coal dust. 


\section{Materials and Methods}

\section{Study Design}

This study was laboratory experiment research, conducted in the Biochemistry and Biomolecular laboratory of Faculty of Medicine Lambung Mangkurat University, Pathology Anatomy laboratory of Faculty of Medicine Lambung Mangkurat University, and DISVIE Clinical laboratory. This research has received ethical approval from the ethics commission Faculty of Medicine Lambung Mangkurat University No.577/KEPK-FK $\mathrm{ULM} / \mathrm{EC} / \mathrm{IV} / 2021$.

\section{The group of study and procedure of the experiment}

A total of 24 female squeaks BALB/c (Mus Musculus) 6-12 weeks old, weight 20-25 g with a healthy state divided randomly into four groups, six mice in each group. The control group (K) was a group that was sensitized with normal saline. The remaining three groups were sensitized and challenged with ovalbumin (OVA) and coal dust. Mice were initially sensitized with intraperitoneal injections of ovalbumin (OVA) solution with alum on days 0 and 14 . Re-sensitizing is done by giving OVA $1 \%$ inhalation 20 minutes/day/ three times in a week repeated for eight weeks as scheduled, at approximately the same time on each treatment. Meanwhile, after four weeks of OVA inhalation, continually exposed to coal dust (CD) $12.5 \mathrm{mg} / \mathrm{m}^{3} / 1$ hour/day for four weeks. Administration of salbutamol nebulizer $1 \%$ or $R$. tomentosa leaves extract $200 \mu \mathrm{g} / 8 \mathrm{ml} \mathrm{NaCl} 0.9 \%$ is done in conjunction with CD exposure. The P1 group: OVAsensitized + coal dust, the P2 group: OVAsensitized + coal dust + salbutamol $1 \%$ and group P3: OVA-sensitized + coal dust + ethanol extract of $R$. tomentosa leaves (EERTL) nebulizer. The mice were injected with ketamine $(150 \mathrm{mg} / \mathrm{kg}$ body weight) and midazolam $(0.5 \mathrm{mg} / \mathrm{kg}$ body weight $)$ in the abdominal cavity and sacrificed after eight weeks of treatments. Bronchoalveolar lavage fluid is taken by rinsing the lung with $\mathrm{NaCl}$ $0.9 \%$ three times with a final volume of 800 $\mathrm{ml}$. The $300 \mathrm{~g}$ BAL liquid concentration was centrifuge for 5 minutes. Then continue with Haematoxylin Eosin (HE) staining for histological examination.

Measurement of the number of eosinophils, neutrophils, lymphocytes

Three observers calculated eosinophil, neutrophil, and lymphocyte on BAL fluid with a blind test using a light microscope with a magnification of $400 \mathrm{x}$, then averaged the results.

\section{Histomorphometry of mice lung tissue}

Measurement of epithelial and smooth muscle thickness is observed by HE staining. Meanwhile, examination of goblet cells using Periodic Acid Schiff (PAS) staining. Masson's Trichome staining observed measurements of the thickness of bronchioles subepithelial fibrosis, collagen deposition by analyzing blue-stained postive regions selected under the basal membrane. Slides were marked with a light microscope (Olympus BX51), magnification of 100x and $400 x$. Images were photographed using a digital camera (Olympus DP71). Morphometry analysis for structural changes using Image-Pro Plus 6.1 software (Media Cybernetics, Silver Spring, MD).

\section{Statistical Analysis}

The calculation data was conducted using the Shapiro-Wilk normality test and homogeneity test using Levene Test. The analysis continued with the One-Way ANOVA and Least Significance Different (LSD) test using SPSS 24. Statistical tests were considered significant if the $\mathrm{p}$-value was less than $0.05(\mathrm{p}<0.05)$.

\section{Results}

The number of eosinophils, neutrophils, and lymphocytes in bronchoalveolar lavage

The study data results on the number of eosinophils of BAL liquid are presented in Fig. 1. Eosinophil cells obtained was performed normality test using Shapiro-Wilk and homogeneity test using Levene Test. The test results obtained $p>0.05$, meaning that the data is normal and homogeneous. Furthermore, a 
parametric test of One-Way ANOVA was conducted that showed $p=0.000(p<0.05)$, which means there is a difference in each group. Test results of LSD 5\% showed significant differences between the control groups $(1.667 \pm 0.816)$ and group $\mathrm{P} 1$ $(4.833 \pm 0.753) \quad(p=0.000), \quad P 1 \quad$ and $P 2$ $(2.167 \pm 0.753) \quad(p=0.000), \quad P 1 \quad$ and $P 3$

\section{$(2.333 \pm 0.816)(\mathrm{p}=0.000)$.}

The results showed that eosinophil number in the treatment group were higher than the control group (K). The number of eosinophil cells given salbutamol nebulizer or ethanol extract of $R$. tomentosa leaves was less than the sensitized OVA and exposed to coal dust group.
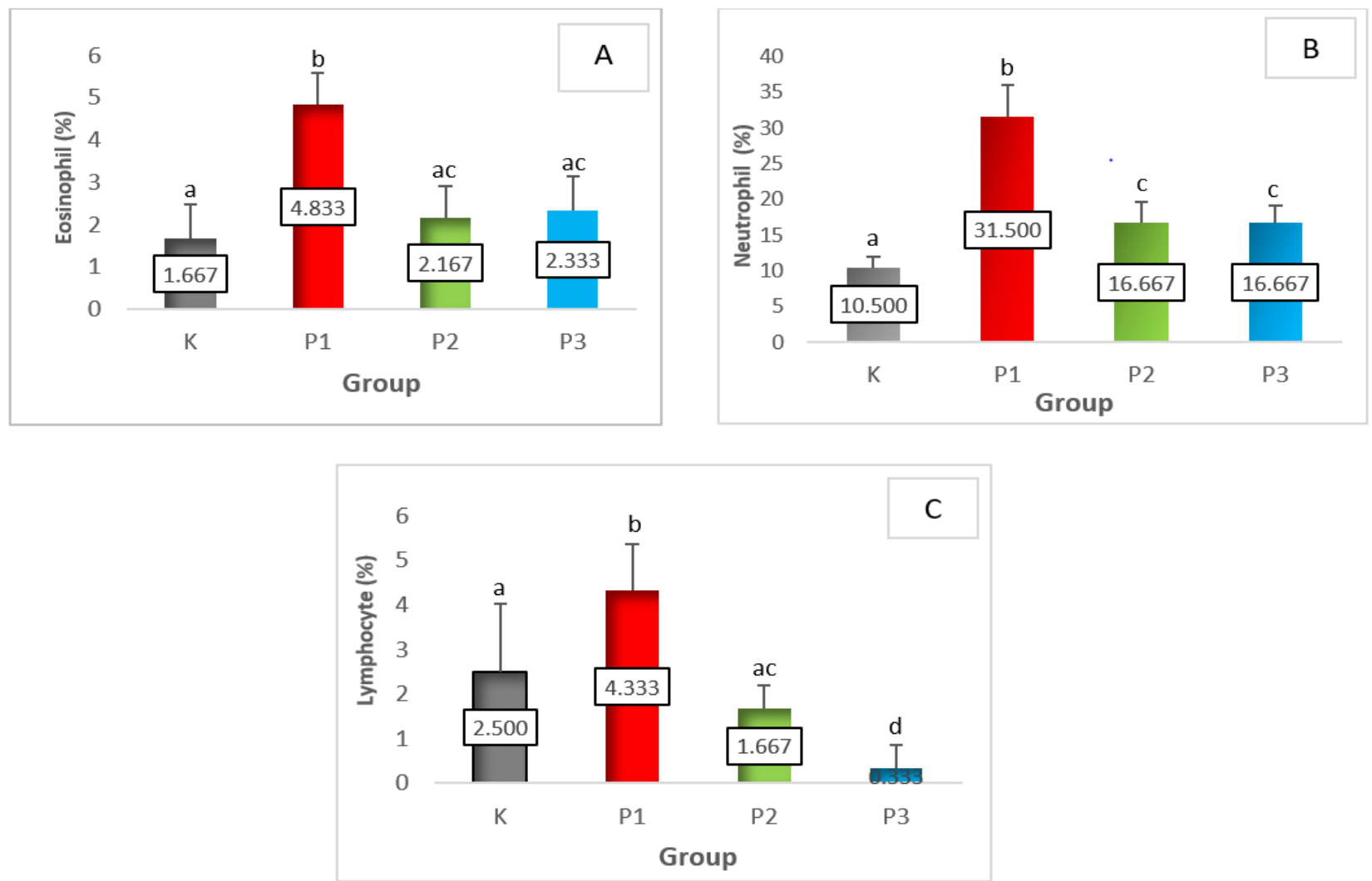

Fig. 1. The average and inequality of the number of eosinophil (A), neutrophil (B), and lymphocyte cells (C) of all groups. $\mathrm{K}=$ control; $\mathrm{P} 1=\mathrm{OVA}+$ coal dust; $\mathrm{P} 2=\mathrm{OVA}+$ coal dust + salbutamol; $\mathrm{P} 3=\mathrm{OVA}+$ coal dust+EERTL. The notation $a, b, c, d$ shows a statistically significant difference if the letter differs $(p<0.05)$.

The number of neutrophils of the P2 and $\mathrm{P} 3$ groups was less than the P1 group. The number of neutrophils of the control group was no different from the $\mathrm{P} 2$ and $\mathrm{P} 3$ groups. ANOVA test results obtained value $\mathrm{p}=0.000$ $(p<0.05)$, continued with post hoc test LSD $5 \%$, there was a significant difference between the number of neutrophils of the P1 group $(31.500 \pm 4.416)$ and $\mathrm{K}$ group $(10.500 \pm 1.472) \quad(p=0.000), \quad P 1$ and $P 2$ $(16.667 \pm 3.011) \quad(p=0.000), \quad P 1$ and $P 3$ $(16.667 \pm 2.503)(\mathrm{p}=0.000), \mathrm{K}$ and $\mathrm{P} 2(\mathrm{p}=$ $0.002), K$ and $P 3(p=0.002)$. The statistics showed no significant difference in neutrophil cell count between $\mathrm{P} 2$ and $\mathrm{P} 3$ groups $(\mathrm{p}=$ 1.000) (Fig. 1).

ANOVA analysis shows a difference in the number of lymphocytes between treatment groups $(p=0.000)$. Test results of post hoc test LSD 5\% was found that there was a significant difference in the number of lymphocytes between the $\mathrm{K}$ group $(2.500 \pm 1.517)$ and $\mathrm{P} 1 \quad(4.333 \pm 1.033)(\mathrm{p}=$ $0.004), K$ and $P 3(0.333 \pm 0.516)(p=0.001)$, $\mathrm{P} 1$ and $\mathrm{P} 3(\mathrm{p}=0.000), \mathrm{P} 1$ and $\mathrm{P} 2(\mathrm{p}=0.000)$, $P 2$ and P3 $(p=0.03)$. There was no significant difference between group $\mathrm{K}$ and $\mathrm{P} 2$ lymphocyte cells $(p=0.159)$ (Fig. 1). The 
number of lymphocyte cells of the group given nebulizer extract ethanol leaves $R$. tomentosa was less than other groups.

\section{Epithelial thickness, smooth muscle, fibrosis subepithelial bronchioles, and the number of goblet cells}

The average thickness of the epithelial bronchioles is shown in Fig. 2. Statistical
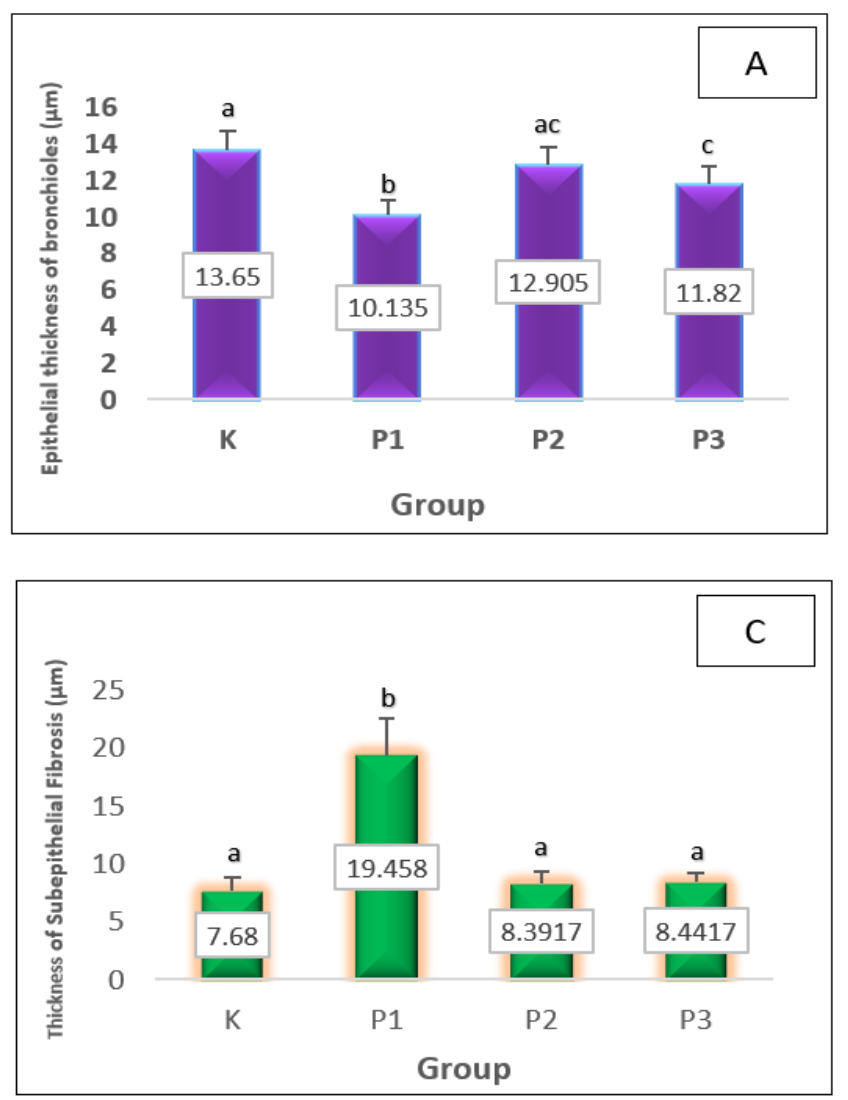

Fig. 2. The average epithelial thickness (A), the smooth muscle (B), and subepithelial fibrosis (C) of mice bronchioles, and the number of goblet cells (D). $\mathrm{K}=$ Control; $\mathrm{P} 1=\mathrm{OVA}+$ coal dust; $\mathrm{P} 2=\mathrm{OVA}+$ coal dust + salbutamol; $\mathrm{P} 3=\mathrm{OVA}+$ coal dust + EERTL. Values presented in average \pm SD. The notation a,b,c,d shows a statistically significant difference if the letter differs $(\mathrm{p}<0.05)$.

The average thickness of the smooth muscle treatment group is fully presented in Fig. 2. The results of the ANOVA statistical analysis followed by the LSD test obtained a meaningful difference in the thickness of smooth muscle cells between the $\mathrm{K}$ group (4.482 \pm 0.689$)$ and P1 (11.572 \pm 1.284$)$, pvalue $=0.000 ; \mathrm{K}$ and $\mathrm{P} 2(6.168 \pm 0.725) \mathrm{p}-$ value $=0.003 ; \mathrm{K}$ and $\mathrm{P} 3(7.277 \pm 0.651), \mathrm{p}-$ value $=0.000 ; \mathrm{P} 1$ and $\mathrm{P} 2$, $\mathrm{p}$-value $=0.000 ; \mathrm{P} 1$

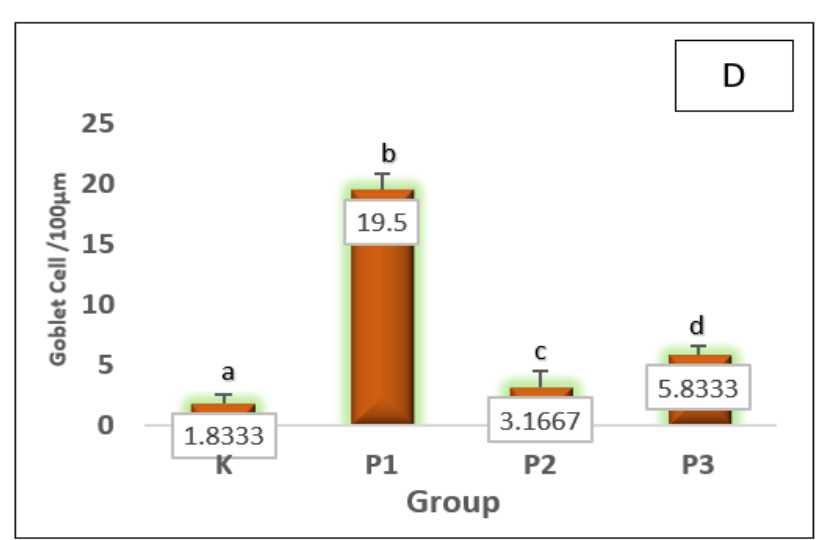

analysis of ANOVA followed by LSD test obtained significant differences between group $\mathrm{K}(13.650 \pm 1.041)$ and P1 $(10.135 \pm 0.800)$ $(\mathrm{p}=0.000), \mathrm{K}$ and $\mathrm{P} 3 \quad(11.820 \pm 0.944) \quad(\mathrm{p}=$ $0.003), P 1$ and P2 ( $p=0.000), P 1$ and P3 ( $p=$ 0.006 ). The $\mathrm{P} 2$ group had higher epithelial thickness than the $\mathrm{P} 3$ group $(\mathrm{p}=0.06)$ and lower than the control group $(\mathrm{p}=0.187)$, but both were not significant statistically.

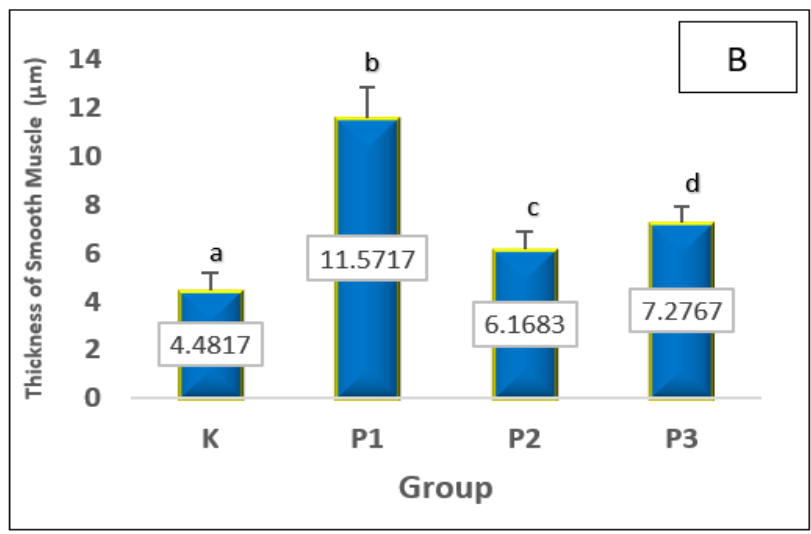




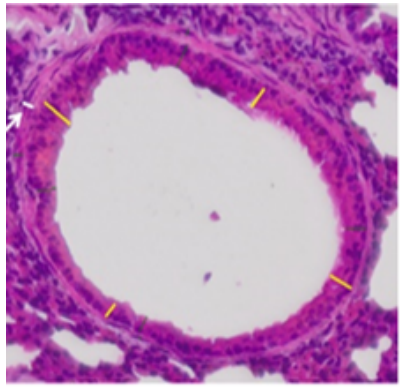

K

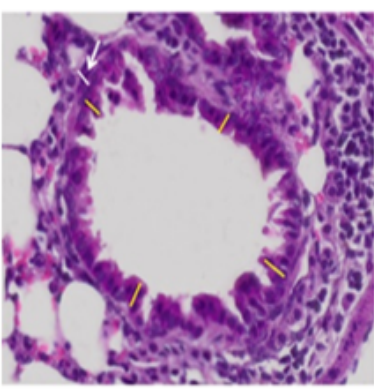

P1

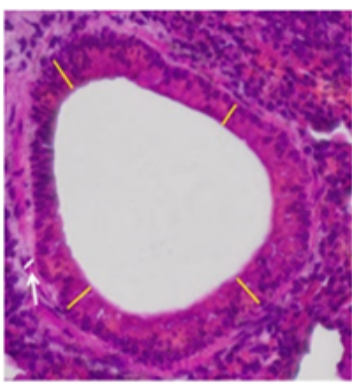

P2

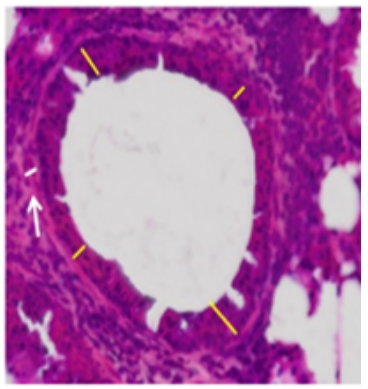

P3

Fig. 3. Overview of epithelial histology and smooth muscle of the mice bronchioles with HE staining (400x magnification), yellow marks indicate epithelial thickness. White marks indicate smooth muscle. $\mathrm{K}=\mathrm{Control}$; $\mathrm{P} 1=$ OVA +coal dust; P2= OVA+coal dust+salbutamol; P3= OVA+coal dust+EERTL.

The results of the data analysis with ANOVA followed by LSD tests obtained significant differences in the thickness of fibrosis of bronchioles subepithelial between K (7.680 \pm 1.134$)$ and P1 (19.458 \pm 3.098$)$, pvalue $=0.000 ; \mathrm{P} 1$ and $\mathrm{P} 2(8.392 \pm 0.950), \mathrm{p}=$ 0.000; P1 and P3 (8.442 \pm 0.728$)$. Meanwhile, no significant difference between groups $\mathrm{K}$ and $\mathrm{P} 2(\mathrm{p}=0.476), \mathrm{K}$ and $\mathrm{P} 3(\mathrm{p}=0.446), \mathrm{P} 2$ and P3 $(\mathrm{p}=0.96)$.

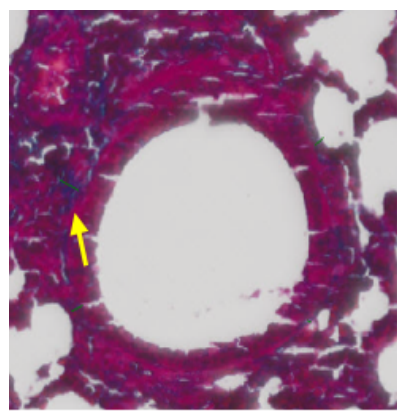

$\mathrm{K}$

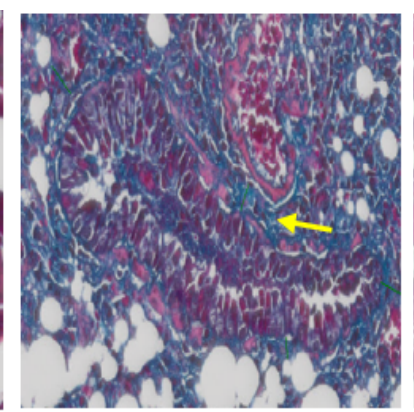

P1

Fig. 4. shows the subepithelial fibrosis of bronchioles mice with the staining of Masson's Trichrome (blue colour). The thickness of subepithelial fibrosis group P2 was more numerous than in other groups. The fibrosis subepithelial bronchioles in the EERTL group (P3) were thinner than the P1 group. That indicates that ethanol extract of $R$. tomentosa leaves may reduce fibrosis.

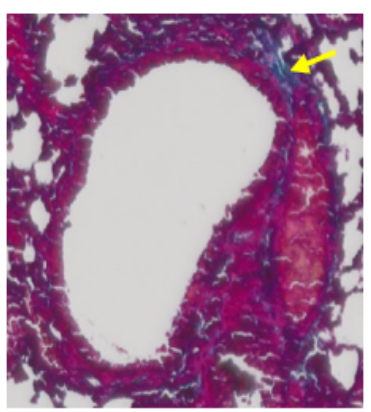

P2

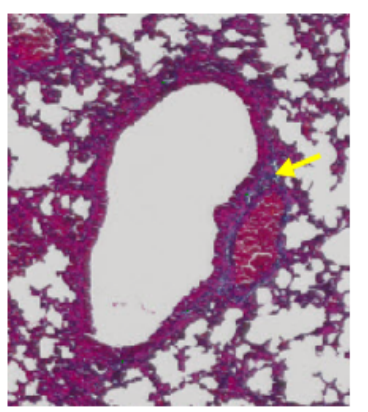

P3

Fig. 4. Histological of fibrosis subepithelial bronchioles of mice with Masson's Trichrome (400x m). The yellow arrow indicates the thickness of subepithelial fibrosis. $\mathrm{K}=$ Control; $\mathrm{P} 1=\mathrm{OVA}+$ coal dust; $\mathrm{P} 2=\mathrm{OVA}+$ coal dust + salbutamol; P3= OVA+coal dust+EERTL.

The results of the analysis of ANOVA data continued with LSD showed a significant difference between goblet cells between $\mathrm{K}$ $(1.833 \pm 0.753)$ and $\mathrm{P} 1 \quad(19.5 \pm 1.378) \quad(\mathrm{p}=$ $0.000), \mathrm{K}$ and $\mathrm{P} 2(3.167 \pm 1.329)(\mathrm{p}=0.048), \mathrm{K}$ and $\mathrm{P} 3(5.833 \pm 0.753)(\mathrm{p}=0.000), \mathrm{P} 1$ and $\mathrm{P} 2$ $(\mathrm{p}=0.000), \mathrm{P} 1$ and $\mathrm{P} 3(\mathrm{p}=0.000), \mathrm{P} 2$ and P3 $(p=0.000)$. The number of goblet cells in the P1 group was greater than in other groups. Administration of ethanol extract of $R$. tomentosa leaves can reduce the number of goblet cells in bronchioles mice asthma + coal dust model (Fig. 2).

Figure 5 shows the histopathology of goblet cells that have vacuoles with PAS staining. P1 group goblet cells (OVA+coal dust), P2 (OVA + coal dust + salbutamol), and P3 (OVA+ coal dust + EERTL) showed an increase in the number and size (hyperplasia) compared to the control group. 


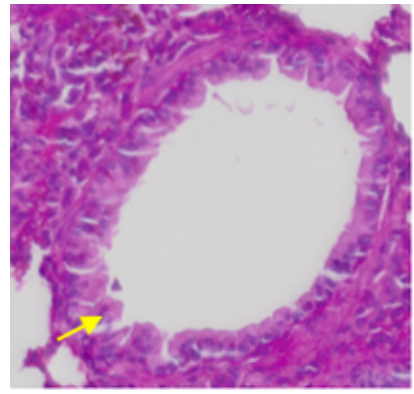

$\mathrm{K}$

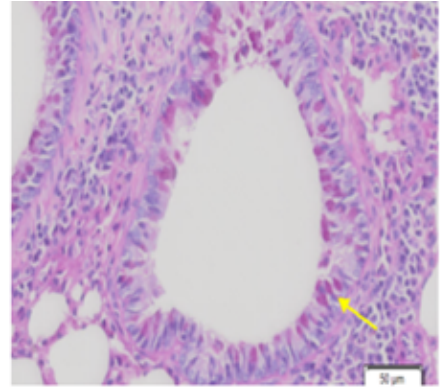

P1

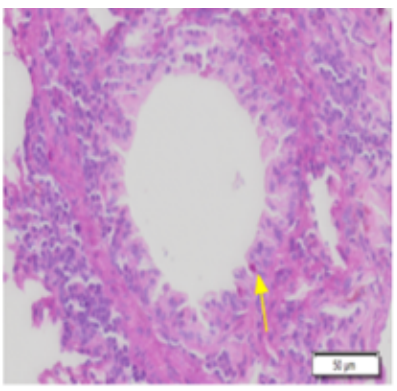

P2

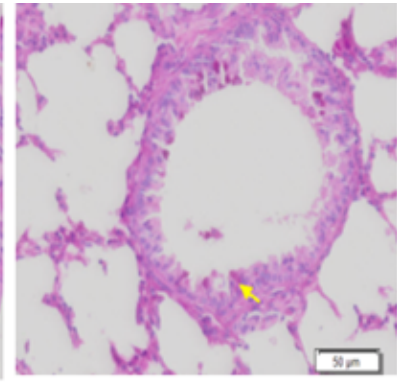

P3

Fig. 5. Image of bronchioles goblet cells of mice with PAS staining (400x magnification). The yellow arrow indicates the goblet cell. $\mathrm{K}=$ Control; $\mathrm{P} 1=\mathrm{OVA}+$ coal dust; $\mathrm{P} 2=\mathrm{OVA}+$ coal dust+salbutamol; $\mathrm{P} 3=\mathrm{OVA}+$ coal dust+EERTL

\section{Discussion}

This study showed that the number of eosinophils, neutrophils, and lymphocytes in the OVAsensitizing mice group and coal dust exposure was greater when compared to the control group. In the OVA-sensitizing mice model, there will be an increase in eosinophil cells and lymphocytes. These cells are the host defense against incoming allergens and activate Th2 cells to produce proinflammatory cytokines that strengthen inflammation (16). Cytokines released by these various cells direct eosinophil cells, basophils, lymphocytes, and others from circulation to lung tissue (17). The Th2 cell's dominant inflammatory eosinophil phenotype may shift to Th1 cells with the involvement of neutrophil cells, primarily describing the severity of asthma. The severity of asthma is characterized by the high number of eosinophil and neutrophil cells in the blood and BAL fluid (18). In this study, the results were due to stimulation from coal dust.

Coal dust can stimulate a host immune system response that induces the release of proinflammatory mediators and cytokines such as TNF- $\alpha$ and IL-1 $\beta$ (19). Coal dust also increases the expression of airway inflammatory cytokines in BAL fluids (IL-1 $\beta$, IL-6, IL-17, and TNF- $\alpha$ ) in models of asthma-induced coal dust released by inflammatory cells (20). The inflammatory process leads to the infiltration of eosinophil cells, neutrophils, and lymphocytes as a defense system of the body against destructive agents. LeónMejía et al. explained that exposure to coal particles and coal dust ash in animals could stimulate the recruitment of polymorphonuclear cells into lung tissue. They are increased respiratory allergy symptoms (21). Coal mine workers exposed without masks and protective clothing for more prolonged periods had a greater frequency of symptoms and impaired upper respiratory tract allergic lung function tests than the control group (22). The proteins bound in PM and acid-soluble transition metals in PM likely cause allergic airway inflammatory pathogenesis (23). Research Huang et al. coal dust activates the transcription factors nuclear factor $\kappa \beta(\mathrm{NF}-\kappa \beta)$ and activator protein 1 (AP-1) in vitro. Activation of transcription factors NF- $\kappa \beta$ and AP-1 triggers an inflammatory response by stimulating the expression of pro-inflammatory genes. Activated macrophages produce products in the form of proinflammatory factors (LTB4, IL-8, IL-6, TNF- $\alpha$ ) that increase in the serum of coal mine workers (24).

The number of eosinophils and neutrophils of the mice group given nebulizer extract ethanol leaves $R$. tomentosa was the same as the control group. That is in line with previous research that $R$. tomentosa can reduce neutrophil infiltration by inhibiting pro-inflammatory cytokine synthesis. The active compound acylphloroglucinol rhodomyrtone in $R$. Tomentose leaf could decrease the expression of genes related to inflammatory processes such as IL-1 $1 \beta$, IL-8, and TNF- $\alpha$ in renal macrophages (25). Interleukin-8 inhibitors such as polyphenols may lower airway neutrophil inflammation (26).

Pro-inflammatory cytokines can increase the activation of inflammatory cells. In the event of inhibition of the secretion of pro-inflammatory mediators can cause decreased activation of inflammatory cells such as eosinophil cells, neutrophils, and lymphocytes. According to the 
results of previous studies showed IL-1 $\beta$ and TNF- $\alpha$ can be inhibited by $R$. tomentosa, thereby decreasing the recruitment of eosinophils and neutrophils (27). The main compounds in $R$. tomentose include flavonoids, saponins, terpenoids (28). Flavonoid compounds have been shown to inhibit eosinophils by decreasing the production of IL-4 and IL-5 through the NF- $\kappa \beta$ pathway (29).

The number of lymphocyte cells in mice given nebulizer extract ethanol leaves $R$. tomentosa less than mice that are not. It shows the influence of active compounds present in the leaves of $R$. tomentosa in reducing the number of lymphocyte cells during inflammation. These results are in line with other studies that show that the content of flavonoid compounds from plants can suppress inflammatory processes characterized by a decrease in the number of lymphocytes (30). Active compounds such as saponins can decrease airway inflammation and lower IL-13, IL-4, IL-5, and IL- 8 in the fluid BAL of animal models of asthma. The compound inhibited the TNF- $\alpha / \mathrm{NF}-$ $\kappa \beta$ pathway in asthma mice and human bronchial epithelial cells (31).

Airway remodelling is a process of airway hyperplasia that contributes to airway hyperactivity and irreversible airflow limitations. Airway remodelling is characterized by increased collagen deposition in the basal membrane regions of the subepithelial and submucosal layers, hypertrophy and smooth muscle hyperplasia, fibroblast hyperplasia, epithelial metaplasia, and goblet cell proliferation $(6,32)$. Poor response to treatment in patients with severe asthma may be a consequence of continuous airway remodelling resulting in permanent airway obstruction $(6,33)$.

The results showed that giving nebulizer extract ethanol leaves $R$. tomentosa can decrease goblet cell hyperplasia based on staining with PAS. Ethanol extract of $R$. tomentosa leaves significantly reduces collagen deposition, as seen from the staining of Masson Trichome. Administration of the EERTL can prevent and inhibit collagen aggregation in the airway remodelling process on a combination of allergen administration and exposure to pollutants. It inhibits the thickening of the airway wall and smooth muscle layer and epithelial hyperplasia based on HE staining of the lungs. These results suggest that the administration of herbal extracts may positively affect pathological changes of airway remodelling.

The composition of $R$. tomentosa leaves previously reported is mainly alkaloid compounds, flavonoids, phenols, tannins, saponins, and terpenoids (34). All of these components contribute as anti-inflammatory and anti-remodelling (32). Flavonoid compounds in Dracocephalum peregrinum L. inhibit the signal of transforming growth factor (TGF)- $\beta 1(14)$. The TGF- $\beta 1$ molecule is an inflammatory cytokine associated with fibrosis (one of the parameters of lung tissue remodelling) in asthma (35). Acylphloroglucinol rhodomyrtone in the ethanol extract of $R$. tomentosa leaves can decrease the expression of genes such as IL- $1 \beta$, IL- 8 , TNF- $\alpha$ $(25,27)$. IL-1 $\beta$ increases the expression of osteopontin pro-fibrotic molecules in fibroblasts (36). Interleukin-8 drivers of cellular ageing or cessation of the cell cycle allow contributing to airway remodelling. Overproduction of IL-1 $\beta$, IL8 , TNF- $\alpha$ by macrophage and fibroblast cells leads to increased inflammation and tissue damage that eventually forms tissue remodelling (6). Ingredients that can inhibit the release of such mediators allow for decreased inflammation and airway remodelling.

This research results show that nebulizer extract ethanol Karamunting leaves (R. tomentosa) can significantly reduce the number of eosinophils, neutrophils, and lymphocytes in a combination model of asthma and coal dust. It can also reduce lung tissue remodelling by decreasing the thickness of epithelial cells, smooth muscle cells, fibrosis of bronchioles subepithelial, and the number of goblet cells in the same combination mice model and coal dust.

\section{Acknowledgements}

Lambung Mangkurat University supported this research through PNBP Grants (No. 010.47/UN8.2/PL/2021). 


\section{References}

1. Kania N, Setiawan B, Nurdiana, Widodo MA, Kusuma HMSC. Lung histopathology changed in coal dust exposure with model 2010 equipment. MKB; 2011; 43:127-33.

2. Kisno Saputri R, Setiawan B, Nugrahenny D, Kania N, Sri Wahyuni E, Widodo MA. The effects of Eucheuma cottonii on alveolar macrophages and malondialdehyde levels in bronchoalveolar lavage fluid in chronically particulate matter 10 coal dust-exposed rats. Iran J Basic Med Sci. 2014;17(7):541-545.

3. Fujiati DA, Mintaroem $\mathrm{K}$, Barlianto $\mathrm{W}$, Widodo MA. Effects of coal dust particulate matter exposure on $\mathrm{H} 2 \mathrm{O} 2$, MDA, IL-13, TGF- $\beta 3$ level and bronchioles sub-epithelial fibrosis in allergic asthma mice model. J Glob Pharma Technol. 2019;11(04, Suppl.):130-9.

4. Ishtiaq M, Jehan N, Khan SA, Muhammad S, Saddique U, Iftikhar B, et al. Potential harmful elements in coal dust and human health risk assessment near the mining areas in Cherat, Pakistan. Environ Sci Pollut Res Int. 2018;25(15):14666-14673.

5. Health Research and Development Agency, Ministry of Health, Republic of Indonesia. Basic Health Research.

2018. http://www.litbang.depkes.co.id

6. Hough KP, Curtiss ML, Blain TJ, Liu RM, Trevor J, Deshane JS, et al. Airway Remodeling in Asthma. Front Med. 2020;7:191.

7. Global Initiative for Asthma. Diagnosis of Diseases of Chronic Airflow Limitation: Asthma COPD and Asthma-COPD Overlap Syndrome (ACOS) Based on the Global Strategy for Asthma Management and Prevention and the Global Strategy for the Diagnosis, Management and Prevention of Chronic Obstructive Pulmonary Disease, 2014;1-12. http://www.ginasthma.org/local/uploads/files/ AsthmaCOPDOverlap.pdf.

8. Henderson I, Caiazzo E, McSharry C, Guzik TJ, Maffia P. Why do some asthma patients respond poorly to glucocorticoid therapy? Pharmacol Res. 2020;160:105189.
9. Jeong D, Yang WS, Yang Y, Nam G, Kim $\mathrm{JH}$, Yoon $\mathrm{DH}$, et al. In vitro and in vivo antiinflammatory effect of Rhodomyrtus tomentosa methanol extract. J Ethnopharmacol. 2013;146(1):205-13.

10. Sutomo, Arnida, Rizki M, Triyasmono L, Nugroho A, Mintowati E, et al. Skrining fitokimia dan uji kualitatif aktivitas antioksidan tumbuhan asal Daerah Rantau Kabupaten Tapin Kalimantan Selatan. J Pharmascience. 2016;3(1):66-74.

11. Ma Q, Jiang JG, Yuan X, Qiu K, Zhu W. Comparative antitumor and anti-inflammatory effects of flavonoids, saponins, polysaccharides, essential oil, coumarin and alkaloids from Cirsium japonicum DC. Food Chem Toxicol. 2019;125:422-429.

12. Bai M, Yao GD, Ren Q, Li Q, Liu QB, Zhang $\mathrm{Y}$, et al. Triterpenoid saponins and flavonoids from licorice residues with anti-inflammatory activity. Industrial Crops and Products. 2018;125:50-58.

13. Tian C, Chang Y, Liu X, Zhang Z, Guo Y, Lan $Z$, et al. Anti-inflammatory activity in vitro, extractive process and HPLC-MS characterization of total saponins extract from Tribulus terrestris L. fruits. Industrial Crops and Products. 2020;150:112343.

14. Yan Y, Liu X, Gao J, Wu Y, Li Y. Inhibition of TGF- $\beta$ Signaling in Gliomas by the Flavonoid Diosmetin Isolated from Dracocephalum peregrinum L. Molecules. 2020;25(1):192.

15. Wang Z, Li L, Wang C, Piao Y, Jiang J, Li L, et al. Recombinant Pyrin Domain Protein Attenuates Airway Inflammation and Alleviates Epithelial-Mesenchymal Transition by Inhibiting Crosstalk Between TGF $\beta 1$ and Notch1 Signaling in Chronic Asthmatic Mice. Front Physiol. 2020;11:559470.

16. Peebles RS, Aronica MA. Proinflammatory Pathways in the Pathogenesis of Asthma. Clin Chest Med. 2019;40(1):29-50.

17. Becerra-Díaz M, Wills-Karp M, Heller NM. New perspectives on the regulation of type II inflammation in asthma. F1000Res. 2017;6:1014. 
18. Esmaeilzadeh A, Elahi R. Immunobiology and immunotherapy of COVID-19: A clinically updated overview. J Cell Physiol. 2021;236(4):2519-2543.

19. Gasparotto J, Chaves PR, da Boit Martinello K, da Rosa-Siva HT, Bortolin RC, Silva LFO, et al. Obese rats are more vulnerable to inflammation, genotoxicity and oxidative stress induced by coal dust inhalation than non-obese rats. Ecotoxicol Environ Saf. 2018;165:44-51.

20. Saba E, Lee Y sil, Yang WK, Lee YY, Kim MK, Woo SM, et al. Effects of a herbal formulation, KGC3P, and its individual component, nepetin, on coal fly dust-induced airway inflammation. Sci Reports. 2020;10(1):1-13.

21. León-Mejía G, Machado MN, Okuro RT, Silva LFO, Telles C, Dias J, et al. Intratracheal instillation of coal and coal fly ash particles in mice induces DNA damage and translocation of metals to extrapulmonary tissues. Sci Total Environ. 2018;625:589-599.

22. Khan ZA, Aslam MI, Ahmad MH, Ahmad MT, Ishaq H, Ahmed Z. Upper Respiratory Allergic Symptoms And Effects Of Coal Dust On Pulmonary Function Tests Of Individuals Working In Coal Mines, Near Quetta, Baluchistan, Pakistan. Adv Basic Med Sci. 2021;5(1):7-10.

23. Ogino K, Nagaoka K, Ito T, Takemoto K, Okuda T, Nakayama SF, et al. Involvement of PM2.5-bound protein and metals in PM2.5induced allergic airway inflammation in mice. Inhal Toxicol. 2018;30(13-14):498-508.

24. Huang C, Li J, Zhang Q, Huang X. Role of bioavailable iron in coal dust-induced activation of activator protein-1 and nuclear factor of activated $\mathrm{T}$ cells: difference between Pennsylvania and Utah coal dusts. Am J Respir Cell Mol Biol. 2002;27(5):568-74.

25. Na-Phatthalung $P$, Teles $M$, Voravuthikunchai SP, Tort L, Fierro-Castro C. Immunomodulatory effects of Rhodomyrtus tomentosa leaf extract and its derivative compound, rhodomyrtone, on head kidney macrophages of rainbow trout (Oncorhynchus mykiss). Fish Physiol Biochem. 2018;44(2):543-555.
26. Herath KHINM, Mihindukulasooriya SP, Kim HJ, Kim A, Kim HJ, Jeon YJ, et al. Oral administration of polyphenol-rich Sargassum horneri suppresses particulate matter exacerbated airway inflammation in murine allergic asthma: Relevance to the TLR mediated NF- $\kappa$ B pathway inhibition. J Funct Foods. 2020;71:103991.

27. Vo TS, Ngo DH. The health beneficial properties of rhodomyrtus tomentosa as potential functional food. Biomolecules. 2019;9(2):76.

28. Zhao Z, Wu L, Xie J, Feng Y, Tian J, He X, et al. Rhodomyrtus tomentosa (Aiton.): A review of phytochemistry, pharmacology and industrial applications research progress. Food Chem. 2020;309:125715.

29. Balkrishna A, Solleti SK, Singh H, Tomer M, Sharma N, Varshney A. Calcio-herbal formulation, Divya-Swasari-Ras, alleviates chronic inflammation and suppresses airway remodelling in mouse model of allergic asthma by modulating pro-inflammatory cytokine response. Biomed Pharmacother. 2020;126:110063.

30. Hwang JY, Randall TD, Silva-Sanchez A. Inducible Bronchus-Associated Lymphoid Tissue: Taming Inflammation in the Lung. Front Immunol. 2016;7:258.

31. Xue K, Ruan L, Hu J, Fu Z, Tian D, Zou W. Panax notoginseng saponin R1 modulates TNF$\alpha / \mathrm{NF}-\kappa \mathrm{B}$ signaling and attenuates allergic airway inflammation in asthma. Int Immunopharmacol. 2020;88:106860.

32. Tang X, Nian H, Li X, Yang Y, Wang X, Xu $\mathrm{L}$, et al. Effects of the combined extracts of Herba Epimedii and Fructus Ligustrilucidi on airway remodeling in the asthmatic rats with the treatment of budesonide. BMC Complement Altern Med. 2017;17(1):380.

33. Zhang J, Dong L. Status and prospects: personalized treatment and biomarker for airway remodeling in asthma. $\mathrm{J}$ Thorac Dis. 2020;12(10):6090-6101.

34. Sutomo A, Hernawati F, Yuwono M. A pharmacognostic study of karamunting leaves (Rhodomyrtus tomentosa) from Pelaihari, South Kalimantan. Sci Appl Chem. 2010;4(1):38-50. 
35. Wang Y, Jing W, Qu W, Liu Z, Zhang D, Qi $\mathrm{X}$, et al. Tectorigenin inhibits inflammation and pulmonary fibrosis in allergic asthma model of ovalbumin-sensitized guinea pigs. J Pharm Pharmacol. 2020;72(7):956-968.
36. Shimodaira T, Matsuda K, Uchibori T, Sugano M, Uehara T, Honda T. Upregulation of osteopontin expression via the interaction of macrophages and fibroblasts under IL-1b stimulation. Cytokine. 2018;110:63-69. 